\title{
PENERAPAN MODEL PEMBELAJARAN BERBASIS MASALAH (PBM) UNTUK MENINGKATKAN AKTIVITAS DAN HASIL BELAJAR IPA MATERI SISTEM PERNAPASAN SISWA KELAS VIIIB SMPN 7 KOTA BENGKULU
}

\author{
Firda Susminiarti ${ }^{{ }^{*}}$, Irwandi Ansori ${ }^{1}$, Yennita ${ }^{1}$ \\ ${ }^{1}$ Program Studi Pendidikan Biologi, Fakultas Keguruan dan Ilmu Pendidikan, Universitas Bengkulu \\ E-mail : Firdasusminiarti009@gmail.com
}

\begin{abstract}
Abstrak
Penelitian ini bertujuan untuk mendeskripsikan aktivitas mengajar guru, aktivitas belajar siswa dan meningkatkan hasil belajar dengan menerapkan model Pembelajaran Berbasis Masalah (PBM) pada materi Sistem Pernapasan di kelas VIIIB SMPN 7 Kota Bengkulu. Jenis penelitian ini termasuk dalam penelitian tindakan kelas dengan metode deskriptif. Penelitian ini terdiri dari dua siklus, masing-masing siklus terdiri dari empat tahap yaitu perencanaan, pelaksanaan, pengamatan dan refleksi. Subyek penelitian ini adalah guru dan seluruh siswa kelas VIIIB SMPN 7 Kota Bengkulu tahun ajaran 2017/2018. Instrumen penelitian yang digunakan adalah lembar tes dan lembar observassi. Lembar observasi terdiri dari lembar observasi guru dan lembar observasi siswa. Variabel penelitian ini adalah model Pembelajaran Berbasis Masalah, aktivitas mengajar guru, aktivitas belajar siswa, dan hasil belajar siswa. Hasil analisis data aktivitas guru siklus I diperoleh skor rata-rata yaitu 28 (Baik), pada siklus II skor aktivitas guru menjadi 30,5 (Baik). Hasil analisis data aktivitas siswa pada siklus I diperoleh skor rata-rata 29 (Baik), dan pada siklus II skor aktivitas siswa menjadi 31,5 (Baik). Selanjutnya data hasil belajar siswa pada siklus I dianalisis berdasarkan kriteria ketuntasan belajar klasikal dan di peroleh nilai rata-rata siswa 72 dengan persentase ketuntasan belajar klasikal 72,4 \% dengan kriteria belum tuntas dan pada siklus II nilai rata-rata siswa meningkat menjadi 82,5 dengan persentase ketuntasan belajar 86,2 \% dengan kriteria tuntas. Dari hasil penelitian menunjukan bahwa penelitian dengan menggunakan model Pembelajaran Berbasis Masalah dapat meningkatkan aktivitas guru, aktivitas siswa dan hasil belajar siswa kelas VIIIB SMPN 7 Kota Bengkulu.
\end{abstract}

Kata Kunci: Pembelajaran Berbasis Masalah, aktivitas, hasil belajar

\begin{abstract}
This study aims to describe teacher teaching activities, learning activities of students and improve learning outcomes by applying Problem-Based Learning model (PBM) on Respiratory System materials in class VIIIB SMPN 7 city of Bengkulu. This type of research is included in classroom action research with descriptive method. This study consists of two cycles, each cycle consists of four stages of planning, implementation, observation and reflection. The subject of this research is teachers and all students of class VIIIB SMPN 7 Kota Bengkulu academic year 2017/2018. The research instrument used is test sheet and observation sheet. The observation sheet consists of teacher observation sheet and student observation sheet. The variables of this research are Problem Based Learning model, teacher teaching activity, student learning activity, and student learning outcomes. The results of data analysis of teacher activity cycle I obtained the average score of 28 (Good), on the second cycle of teacher activity scores to 30.5 (Good). The result of data analysis of student activity in cycle I obtained average score 29 (Good), and in cycle II student activity score become 31,5 (Good). Furthermore the data of student learning outcomes in the first cycle is analyzed based on the criteria of classical learning completeness and in the average score of 72 students with the percentage of classical learning completeness of $72.4 \%$ with unfinished criteria and in cycle II the average student score increased to 82.5 with percentage of learning mastery $86,2 \%$ with complete criterion. From the results of research shows that research by using Problem-Based Learning model can increase teacher activity, student activity and student learning outcomes of grade VIIIB SMPN 7 city of Bengkulu.
\end{abstract}

Keywords: Problem Based Learning, activity, learning outcomes

\section{PENDAHULUAN}

Pasal 1 ayat (1) Undang-Undang Nomor 20 tahun 2003 tentang Sistem 
9669

Pendidikan Nasional menjelaskan bahwa pendidikan dinyatakan sebagai usaha dasar dan terencana untuk mewujudkan suasana belajar dan proses pembelajaran agar peserta didik secara aktif mengembangkan potensi dirinya. Belajar bukan hanya sekedar menghafal, melainkan suatu proses mental yang terjadi dalam diri seseorang. Sedangkan pembelajaran pada hakikatnya merupakan suatu proses interaksi antara guru dengan siswa, baik interaksi secara langsung seperti kegiatan tatap muka maupun secara tidak langsung (Rusman, 2014).

Perkembangan ilmu pengetahuan dan teknologi yang pesat di era global sekarang ini menuntut individu untuk berkembang menjadi manusia berkualitas yang memiliki pemikiran kreatif dalam menjawab segala tantangan dan permasalahan yang ada. Pendidikan sebagai salah satu sistem yang menjawab tuntutan ini juga mengalami perubahan seiring dengan perkembangan zaman, perubahan ini terkait dengan proses pembelajaran yang berlangsung di dalam kelas. Proses pembelajaran yang mampu mengembangkan potensi dan kreativitas peserta didik diperlukan dalam era yang terus berkembang saat ini (Khalifah, 2013).

Berdasarkan hasil observasi dan diskusi dengan guru biologi kelas VIII SMP Negeri 7 Kota Bengkulu yang dilakukan peneliti terhadap pembelajaran di kelas, permasalahan pembelajaran yang dapat diidentifikasi dari kelas tersebut adalah aktivitas dan hasil belajar siswa yang masih kurang maksimal, adapun yang terjadi pada siswa antara lain: 1) siswa kurang aktif dalam proses pembelajaran yang sedang berlangsung seperti bertanya dan menyatakan pendapat, sehingga mereka tidak terbiasa mengembangkan kemampuan berpikirnya dan akhirnya mereka hanya menerima informasi saja; 2) kebanyakan siswa tidak memiliki pengetahuan awal terhadap materi yang diajarkan sehingga kurang memahami materi yang disampaikan akibatnya siswa tidak bisa memecahkan masalah yang ada dan membuat siswa tidak bisa mengaitkan masalah tersebut dengan kehidupan sehari-hari; 3) Dalam proses pembelajaran, masih banyak siswa yang ribut dan melakukan aktivitas lain diluar konteks belajar, seperti mengobrol dan keluar masuk kelas. Selain itu guru masih jarang melibatkan siswa sehingga pembelajaran masih berpusat pada guru, guru masih sangat jarang mengaitkan materi pembelajaran dengan masalah nyata di kehidupan sehari-hari siswa.

Rendahnya aktivitas siswa sejalan dengan rendahnya hasil belajar siswa. Hal ini terbukti dari persentase nilai hasil belajar Biologi siswa kelas VIII hanya 14 orang siswa yang tuntas belajarnya dari 26 orang siswa. Berdasarkan Kriteria Ketuntasan Minimal (KKM) di SMP N 7 Kota Bengkulu yaitu $\geq 70$ dengan ketuntasan belajar klasikal $\geq 80 \%$ hal ini berarti hanya $54 \%$ (14 orang) siswa kelas VIII yang tuntas belajar IPA secara klasikal. Harapannya nilai dari hasil belajar lebih meningkat pada semua siswa dan $80 \%$ siswa mendapatkan nilai $\geq 70$.

Masalah pembelajaran yang dihadapi guru dan siswa di atas, salah satunya dapat diatasi dengan mengembangkan model Pembelajaran Berbasis Masalah yang dilakukan sesuai dengan langkahlangkahnya secara utuh, selain itu masalah tersebut juga perlu diatasi terkait dengan tujuan pokok penyelenggaraan kegiatan pembelajaran yaitu membelajarkan siswa agar mampu memproses dan memperoleh pengetahuan, keterampilan, dan sikap bagi diri sendiri.

Berdasarkan data dan informasi di atas, maka peneliti bekerjasama dengan guru mata pelajaran Biologi di SMP N 7 Kota Bengkulu dalam menentukan perbaikan pembelajaran Biologi di kelas VIII melalui Penelitian Tindakan Kelas dengan 


\section{9}

menerapkan model Pembelajaran Berbasis

Masalah untuk meningkatkan aktivitas dan hasil belajar siswa.

Pembelajaran dengan model PBM ini dipilih berdasarkan permasahan yang ada di kelas VIIIB SMPN 7 Kota Bengkulu karena dalam model PBM dapat membuat siswa belajar melalui upaya penyelesaian permasalahan dunia nyata (real word problem) secara terstruktur untuk mengonstruksi pengetahuan siswa dan dalam PBM kemampuan berpikir siswa betul-betul dioptimalisasikan melalui proses kerja kelompok atau tim yang sistematis, sehingga siswa dapat memberdayakan, mengasah, menguji, dan mengembangkan kemampuan berpikirnya secara kesinambungan (Dahar, 2011).

Pembelajaran Berbasis Masalah ini menuntut siswa untuk aktif melakukan penyelidikan dalam penyelesaian permasalahan dan guru berperan sebagai fasilitator atau pembimbing. Pembelajaran akan dapat membentuk kemampuan siswa untuk berfikir tingkat tinggi (higher order thinking) dan meningkatkan kemampuan siswa untuk berpikir kritis (Sani, 2014).

\section{METODE}

Penelitian ini merupakan Penelitian Tindakan Kelas (PTK) dengan metode deskriptif yang dilakukan dalam dua siklus, setiap siklus terdiri tahap perencanaan, pelaksanaan, pengamatan dan refleksi (Kunandar, 2011).

Metode penelitian yang digunakan dalam penelitian ini adalah metode deskriptif untuk mendeskripsikan aktivitas dan hasil belajar biologi siswa dengan menerapkan model Pembelajaran Berbasis Masalah di SMPN 7 Kota Bengkulu.

Subjek penelitian pada penelitian ini adalah guru dan seluruh siswa kelas VIIIB SMPN 7 Kota Bengkulu tahun ajaran 2017/2018 yang berjumlah 29 orang yang terdiri dari 12 orang laki-laki dan 17 orang perempuan.
Teknik pengumpulan data dalam penelitian ini adalah observasi dan tes. Instrumen yang digunakan dalam penelitian ini yaitu lembar observasi dan lembar tes. Instrumen yang digunakan dalam penelitian ini yaitu lembar observasi dan lembar tes. Dalam penelitian ini lembar observasi yang digunakan yaitu lembar observasi aktivitas mengajar guru dan lembar observasi aktivitas belajar siswa pada materi Sistem Pernapasan. Instrumen yang digunakan untuk mengumpulkan data ketuntasan hasil belajar digunakan lembar tes dalam bentuk tes Essai.

Data hasil observasi aktivitas guru dan aktivitas siswa dianalisis dengan menentukan nilai rata-rata yang diperoleh dari 2 orang pengamat dengan menggunakan rumus:
1) Rata-rata skor $=\frac{\text { Jumlah skor }}{\text { Jumlah pengamat }}$
2) Skor tertinggi = Jumlah butir pengamatan $\times$ skor tertinggi tiap butir pengamatan
3) Skor terendah = Jumlah butir pengamatan $\times$ skor terendah tiap butir pengamatan
4) Selisih skor $=$ Skor tertinggi - Skor terendah
5) Kisaran nilai untuk tiap kriteria $=\frac{\text { Selisih } \text { skor }}{\text { Jumlah kriteria penilaian }}$

(Arikunto, 2012).

Kisaran rerata skor observasi aktivitas guru dan siswa terdiri dari 3 kategori, yaitu Baik, Cukup, dan Kurang. Kisaran rerata tersebut dapat dilihat pada Tabel 1.

Tabel 1. Kisaran nilai observasi guru dan siswa

\begin{tabular}{cc}
\hline Interval & Kriteria \\
\hline $27-34$ & Baik \\
$19-26$ & Cukup \\
$11-18$ & Kurang \\
\hline
\end{tabular}


Diklabio: Jurnal Pendidikan dan Pembelajaran Biologi 3(1): 90-99 (Mei 2019) e-ISSN 25989669

Untuk menganalisis data hasil belajar kognitif siswa dapat dihitung dengan menggunakan rumus berikut :

1) Rerata dapat dihitung dengan menggunakan rumus sebagai berikut :

$$
X={ }_{N}^{\sum X}
$$

(Arikunto, 2013)

Keterangan :

$\mathrm{X}$ : Nilai rata-rata kelas

$\sum x$ : Jumlah nilai siswa keseluruhan

$N$ : Jumlah seluruh siswa

2) Persentase Ketuntasan Belajar Klasikal dapat dihitung dengan menggunakan rumus :

$$
K B=\frac{N S}{N} \times 100 \%
$$

(Arikunto, 2013)
Keterangan :

KB : Ketuntasan belajar klasikal

NS : Jumlah siswa yang memperoleh

nilai $\geq 70$

$S$ : Jumlah seluruh siswa

\section{HASIL DAN PEMBAHASAN}

Berdasarkan hasil penelitian yang telah dilaksanakan di kelas VIII ${ }_{B}$ SMPN 7 Kota Bengkulu dengan menerapkan Model Pembelajaran Berbasis Masalah sebanyak 2 siklus pembelajaran yang berfokus pada aktivitas mengajar guru, aktivitas belajar siswa dan hasil belajar siswa pada materi Sistem Pernapasan, diperoleh hasil aktivitas guru dan aktivitas siswa yang dapat dilihat pada Tabel 2 .

Tabel 2. Data Hasil Aktivitas Guru Dan Siswa

\begin{tabular}{ccccc}
\hline Siklus & \multicolumn{2}{c}{ Aktivitas Guru } & \multicolumn{2}{c}{ Aktivitas Siswa } \\
\hline I & Rerata & Kriteria & Rerata & Kriteria \\
II & 28 & Baik & 29 & Baik \\
\hline
\end{tabular}

Dapat dilihat dari tabel diatas bahwa rerata skor aktivitas guru dan aktivitas siswa mengalami peningkatan dari siklus I ke siklus II. Pada siklus I, rerata skor aktivitas guru sebesar 28 dengan kriteria baik, dan pada siklus II mengalami peningkatan menjadi 30,5 dengan kriteria baik. Begitu juga dengan aktivitas siswa pada siklus 1 rerata skor 29 dengan kriteria baik mengalami peningkatan pada siklus II menjadi 31,5 dengan kriteria baik. Data hasil belajar siswa pada siklus I dan Siklus II dapat dilihat Tabel 3

Tabel 3. Data Hasil Persentase Ketuntasan Belajar Klasikal Siswa

\begin{tabular}{ccccc}
\hline Siklus & $\begin{array}{c}\text { Jumlah siswa } \\
\text { yang tuntas }\end{array}$ & $\begin{array}{c}\text { Nilai rata- } \\
\text { rata }\end{array}$ & $\begin{array}{c}\text { Persentase ketuntasan } \\
\text { klasikal }\end{array}$ & Kriteria \\
\hline I & 21 & 72 & $72,4 \%$ & Tidak Tuntas \\
II & 25 & 82,5 & $86,2 \%$ & Tuntas \\
\hline
\end{tabular}

Berdasarkan Tabel 3 dapat diketahui bahwa persentase ketuntasan belajar pada siklus I adalah $72,4 \%$ termasuk kriteria tidak tuntas karena dari jumlah keseluruhan siswa yaitu 29 orang hanya sebanyak 21 orang saja yang mendapatkan nilai $\geq 70$. Berdasarkan kriteria ketuntasan minimal (KKM) yang telah ditetapkan oleh SMP N 7 Kota Bengkulu bahwa suatu pembelajaran dapat dikatakan tuntas secara individual apabila siswa memperoleh nilai $\geq 70$. Sedangkan proses pembelajaran dapat dikatakan tuntas secara klasikal apabila 
terdapat $80 \%$ siswa yang sudah memperoleh nilai $\geq 70$.

Berdasarkan hasil pengamatan dengan penerapan model Pembelajaran Berbasis Masalah terdapat peningkatan aktivitas guru dan siswa. Peningkatan tersebut dapat dilihat pada Grafik 1.

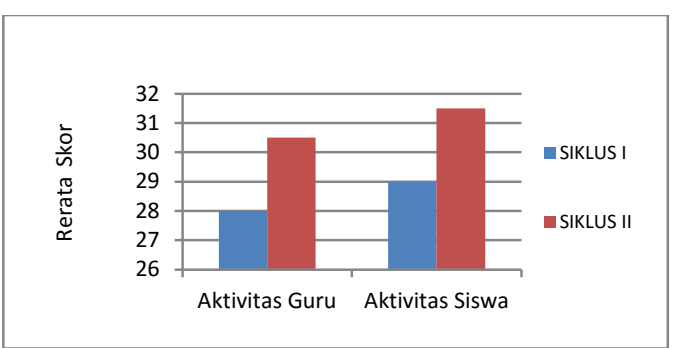

Gambar 1. Grafik aktivitas guru dan aktivitas siswa siklus I dan siklus II

Kegiatan aktivitas mengajar guru dan aktivitas belajar siswa terdapat di dalam setiap sintaks model Pembelajaran Berbasis Masalah berikut :

\section{1) Orientasi siswa pada masalah}

Aspek yang pertama yaitu guru menjelaskan tujuan pembelajaran. Pada aspek ini aktivitas guru dan aktivitas siswa di siklus I belum berjalan dengan baik, akan tetapi mengalami peningkatan pada siklus II. Hal ini dapat dilihat berdasarkan penilaian dari kedua observer yang sebelumnya disiklus I memberikan penilaian dalam kriteria cukup (C) untuk kedua aktivitas guru dan siswa, dan di siklus II memberikan penilaian dalam kriteria baik (B) untuk aktivitas guru tetapi aktivitas siswa masih dalam kriteria cukup karena masih ada sebagian siswa yang hanya memperhatikan tapi tidak mencatatnya di buku.

Kegiatan kedua yaitu guru menyajikan masalah, pada aspek ini aktivitas guru dinilai cukup oleh kedua observer pada siklus 1, kemudian dilakukan refleksi untuk perbaikan di siklus II dengan mengajukan pertanyaan "Apakah kalian tahu contoh gangguan yang ditimbulkan pada sistem pernapasan?" "apa kalian pernah melihat orang yang terkena penyakit asma? Menurut kalian mengapa orang yang terkena asma sulit untuk bernapas?". Namun aspek ini tidak mengalami peningkatan karena masih dinilai cukup (C) oleh kedua observer.

Pada aspek ini seharusnya guru menyajikan situasi kepada masalah tidak hanya dengan mengajukan pertanyaan, tetapi sebaiknya guru juga bisa langsung menampilkan gambar penyebab penyakit asma dan lebih membimbing siswa untuk mengaitkan gambar yang ditampilkan tersebut dengan fenomena yang ada dikehidupan sehari-hari, sehingga guru dapat menyajikan situasi kepada masalah dengan mengajukan pertanyaan sesuai dengan fenomena dan tujuan pembelajaran. Hal ini sesuai dengan pendapat Effendi (2016) yang mengemukakan tugas guru dalam PBM yaitu guru hendaknya menyajikan situasi masalah yang berbeda-beda berupa informasi dan gambar atau yang lainnya. Sedangkan aktivitas siswa dinilai dengan kriteria baik (B) oleh observer di siklus 1 dan tetap dalam kriteria baik di siklus II.

Kegiatan yang ketiga yaitu guru memotivasi siswa untuk terlibat dalam pemecahan masalah dan siswa termotivasi untuk terlibat dalam pemecahan masalah yang dipilih guru dengan mengamati video yang ditampilkan guru. Pada kegiatan ini aktivitas guru dan aktivitas siswa disiklus I dan di siklus II mendapat penilaian dalam kriteria baik (B) oleh observer karena guru memotivasi siswa selain menampilkan video guru juga mengajukan pertanyaan agar siswa terlibat dalam pemecahan masalah.

\section{2) Mengorganisasikan siswa untuk belajar \\ Kegiatan yang pertama di tahap ini} yaitu guru membimbing siswa dalam pembagian kelompok, hal ini bertujuan agar siswa dapat mengembangkan 
kemampuan bersosialisasi dengan temantemannya. Sehingga siswa dapat mengembangkan pemikirannya dalam memecahkan suatu masalah, kesulitan belajar siswa secara individu dapat diatasi melalui kerja kelompok. Pada kegiatan ini aktivitas guru dan siswa memperoleh skor dalam kriteria baik (B).

$$
\text { Kegiatan kedua yaitu guru }
$$
memberikan LKS pada siklus I dan LDS pada siklus II kepada siswa dan menjelaskan langkah kerja di LKS dan LDS dan siswa mengambil LKS pada siklus I dan LDS pada siklus II yang diberikan guru. Pada kedua kegiatan tersebut aktivitas guru dan aktivitas siswa sudah berjalan dengan baik, dapat dilihat dari hasil yang diperoleh dari kedua observer pada siklus I dan siklus II yaitu dalam kriteria baik (B). Pada tahap ini guru membagikan LKS pada siklus I dan LDS pada siklus II kepada 5 kelompok siswa serta menjelaskan langkah kerja pada LKS siklus I dan LDS pada siklus II. Pemberian penjelasan langkah kerja LKS pada siklus I dan LDS pada siklus II sangatlah penting agar proses pengerjaannya sistematis dan teratur. Hal ini juga memudahkan siswa untuk memahami apa yang harus mereka kerjakan sesuai dengan langkah-langkah yang ada pada petunjuk di LKS/LDS.

\section{3) Membimbing pengalaman individual/kelompok}

Kegiatan yang pertama guru membimbing siswa untuk mencapai pemahaman tentang materi sistem pernapasan dengan mengajukan pertanyaan yang sesuai dengan fenomena dan tujuan pembelajaran. Dari aktivitas guru dan siswa pada aspek ini sudah berjalan dengan baik, hal ini dapat dilihat berdasarkan penilaian dari kedua observer yang memberikan nilai dalam kriteria baik (B) pada siklus I. Namun dilihat dari aktivitas guru dan siswa di siklus II pada kegiatan yang pertama ini mendapat penilaian dari observer dalam kriteria cukup (C), hal ini dikarenakan pada siklus II guru membimbing siswa untuk mencapai pemahaman tentang materi sistem pernapasan dengan mengajukan pertanyaan namun pertanyaan tersebut masih kurang tepat. Seharusnya guru lebih menspesifikkan pada 1-2 contoh dari kelainan pada sistem pernapasan sehingga guru dapat membimbing siswa mencapai pemahaman tentang sistem pernapasan. Begitupula pada aktivitas siswa dalam menjawab pertanyaan yang diajukan guru memperoleh penilaian dari observer dalam kriteria cukup karena jawaban yang diberikan siswa belum sesuai dengan fenomena yang diajukan guru.

Kegiatan kedua guru membimbing kelompok untuk mengumpulkan informasi yang sesuai, melakukan diskusi untuk mendapatkan penjelasan dan pemecahan masalah pada materi sistem pernapasan. Pada kegiatan ini diharapkan semua siswa diminta lebih aktif memecahkan masalah yang telah disajikan untuk memecahkan masalah dengan baik. Hal ini sesuai dengan pernyataan Kosasih (2014) PBL juga mendorong siswa untuk terbiasa berkolaborasi dengan temannya. Hal ini karena dalam pelaksanaan model tersebut mereka tidak terlepas dari kegiatan sumbang saran antar siswa yang satu dengan yang lainnya, termasuk dalam rangkaian kegiatan dan usaha dalam menemukan solusinya. Pada kegiatan ini aktivitas guru dan siswa memperoleh skor dalam kriteria baik (B).

\section{4) Mengembangkan dan menyajikan hasil karya}

Kegiatan yang pertama guru membantu siswa dalam merencanakan dan menyiapkan karya berupa laporan hasil diskusi kelompok dan meminta mereka untuk berbagi tugas dengan teman sekelompoknya. Hal ini bertujuan agar mereka bisa menyelesaikan tugas kelompoknya dengan baik dan saling memberikan saran dalam membuat 
laporan diskusi. Hal ini sesuai dengan pernyataan Wisudawati (2014) bahwa PBM menyarankan untuk bekerjasama dalam suatu kelompok. Bekerja berkelompok berguna untuk menyelesaikan masalah yang kompleks menjadi mudah karena bekerja kelompok dapat menambah motivasi dan pengembangan berpikir.

Aktivitas guru dan aktivitas siswa pada siklus I dinilai cukup (C) oleh observer, tetapi setelah dilakukan refleksi mengalami peningkatan di siklus II pada aktivitas guru dinilai baik (B) oleh observer 1, dan observer 2 masih memberikan penilaian dalam kriteria cukup karena menurut observer 2 guru belum melaksanakan kegiatan yang pertama ini dengan maksimal sesuai dengan indikator penilaian lembar observasi yang ada. Aktivitas siswa di siklus II juga mengalami peningkatan karena semua kelompok sudah melakukan kegiatan ini dengan baik. Hal ini terlihat dari perolehan skor yang diberikan oleh observer termasuk dalam kriteria baik (B).

Kegiatan yang kedua guru meminta perwakilan kelompok presentasi didepan kelas untuk mengomuikasikan hasil jawaban pertanyaan dalam LKS dan siswa mewakilkan anggota kelompoknya presentasi didepan kelas. Pada kegiatan ini baik aktivitas guru maupun aktivitas siswa dinilai oleh observer dalam kriteria baik (B) pada siklus I dan II karena siswa sudah menampilkan hasil jawaban pertanyaan dalam LKS. Hal ini sesuai dengan pernyataan Trianto (2011) bahwa hasil penyelesaian masalah siswa dibuatkan laporannya dan ditampilkan didepan kelas.

\section{5) Menganalisis dan mengevaluasi proses pemecahan masalah}

Siklus I proses refleksi yang dilakukan guru dan siswa belum berjalan maksimal dikarenakan waktu yang digunakan untuk berdiskusi kurang, ini membuat pengulasan materi, proses tanya jawab dan pemberian jawaban yang benar dari diskusi dan kegiatan siswa ini mendapatkan penilaian dalam kriteria cukup (C) dari observer. kegiatan ini mengalami peningkatan di siklus II, dapat dilihat dari perolehan skor yang diberikan oleh observer dalam kriteria baik (B).

Untuk mengetahui tingkat keberhasilan siswa selama mengikuti pembelajaran menggunakan model Pembelajaran Berbasis Masalah (PBM), guru memberikan evaluasi berupa tes tertulis dalam bentuk esai yang dilaksanakan pada akhir pembelajaran. Menurut Daryanto (2014), bahwa evaluasi merupakan istilah untuk mengukur dan menilai berdasarkan data yang telah terkumpul dilakukan refleksi sebagai penyempurnaan kegiatan pembelajaran. Pada siklus I masih dinilai cukup oleh observer karena waktu yang diberikan guru untuk siswa menjawab pertanyaan post test masih kurang dan meningkat di siklus II karena waktu yang diberikan untuk menjawab soal tes cukup.

Hasil belajar yang diukur dalam penelitian ini adalah hasil belajar dalam ranah pengetahuan (kognitif). Berdasarkan penelitian tindakan kelas (PTK) yang telah dilakukan selama 2 siklus pembelajaran ini tidak hanya terdapat peningkatan aktivitas guru siswa saja, melainkan juga terdapat peningkatan pada hasil belajar siswa. Peningkatan proses pembelajaran yang terjadi sejalan dengan peningkatan hasil belajar yang dicapai siswa (Arikunto, 2015).

Untuk mengetahui tingkat keberhasilan siswa selama mengikuti pembelajaran dengan menggunakan model Pembelajaran Berbasis Masalah, guru memberikan evaluasi berupa post test diakhir pembelajaran.

Siklus I diketahui jumlah presentase ketuntasan belajar klasikal siswa yang 
tuntas sebesar $72,4 \%$. ini berarti siswa yang memperoleh nilai $\geq 70$ berjumlah 21 orang siswa dari 29 orang siswa yang ada. Presentase keberhasilan hasil belajar siswa sebesar $72,4 \%$ ini masih tergolong rendah dari ketuntasan belajar klasikal yang telah ditetapkan yaitu $80 \%$. Sehingga pada siklus I ketentusan belajar klasikal siswa belum dikatakan tuntas.

Siklus II diketahui ketuntasan belajar klasikal siswa mengalami peningkatan menjadi $86,2 \%$. Sesuai dengan ketentuan yang ditetapkan oleh SMP N 7 Kota Bengkulu adalah $80 \%$ Sehingga pada siklus II ketuntasan belajar klasikal siswa dikatakan tuntas.

Menurut Arifin (2012) guru perlu melakukan penilaian hasil belajar setelah peserta didik mengikuti proses belajar yang didasarkan atas kriteria tertentu. Setelah ditetapkan kriterianya, guru baru dapat menentukan berhasil tidaknya peserta didik, baik dalam proses maupun hasil belajarnya.

\section{PENUTUP}

\section{Simpulan}

Berdasarkan hasil penelitian tindakan kelas VIII ${ }_{B}$ SMPN 7 Kota Bengkulu dengan menerapkan model Pembelajaran Berbasis Masalah pada materi sistem pernapasan, dapat disimpulkan bahwa:

1. Perbaikan pembelajaran dengan menerapkan model Pembelajaran Berbasis Masalah pada materi Sistem Pernapasan di kelas VIII ${ }_{B}$ SMPN 7 Kota Bengkulu dapat meningkatkan aktivitas mengajar guru dan aktivitas belajar siswa.

2. Perbaikan pembelajaran dengan menerapkan model Pembelajaran Berbasis Masalah pada materi Sistem Pernapasan di kelas VIII ${ }_{B}$ SMPN 7 Kota Bengkulu dapat meningkatkan hasil belajar siswa dari siklus I ke siklus II.

\section{Saran}

Berdasarkan hasil penelitian yang telah dilakukan, beberapa saran yang dapat dianjurkan adalah sebagai berikut:

1. Untuk penelitian lanjutan, diharapkan peneliti harus memantapkan strategi pembelajaran lebih baik pada model PBM terutama ditahap orientasi pada masalah, masalah yang disajikan bisa dalam bentuk pertanyaan dan menampilkan gambar/video. Masalah yang diberikan harus berupa masalah dunia nyata/kehidupan sehari-hari yang ada disekitar siswa.

2. Untuk peneliti selanjutnya diharapkan peneliti harus bersikap lebih tegas dalam membagi kelompok siswa pada sintaks model PBM yang kedua yaitu mengorganisasikan siswa untuk belajar agar pada sintaks ini tidak memakan waktu yang lama sehingga mempengaruhi waktu yang diberikan pada sintaks-sintaks selanjutnya.

\section{DAFTAR PUSTAKA}

$\begin{array}{ccc}\text { Arifin, } & \text { Zainal. } 2012 . & \text { Evaluasi } \\ \text { Pembelajaran, Prinsip, } & \text { Teknik, } \\ \text { Prosedur. Bandung: PT } & \text { Remaja } \\ \text { Rosdakarya } & \end{array}$ Arikunto, Suharsimi. 2012. Dasar-dasar Evaluasi Pendidikan. Jakarta : Bumi Aksara

Arikunto, Suharsimi. 2013. Dasar-dasar Evaluasi Pendidikan. Jakarta: PT Bumi Aksara.

Arikunto, Suharsimi, Suhardjono, Supardi. 2015. Penelitian Tindakan Kelas Edisi Revisi. Jakarta : Bumi Aksara.

Dahar, Ratna Wilis. 2011. Teori-Teori Belajar dan Pembelajaran. Jakarta: Erlangga

Daryanto. 2014. Pendekatan Pembelajaran Saintifik Kurikulum 2013. Yogyakarta : Gava Media

Effendi, M. 2016. Peningkatan Aktivitas Dan Hasil Belajar Matematika Melalui Model Pembelajaran 
Diklabio: Jurnal Pendidikan dan Pembelajaran Biologi 3(1): 90-99 (Mei 2019) e-ISSN 25989669

Berdasarkan Masalah Pada Peserta Didik Kelas VI SDN 04 Nan Sabaris Tahun Pelajaran2015/2016. Hosnan, M. 2014. Pendekatan Saintifik dan Kontekstual dalam Pembelajaran Abad 21. Bogor: Ghalia Indonesia.

Khalifah, N Umi. 2013. Penerapan Model Problem-Based Learning Untuk Meningkatkan Aktivitas dan Hasil Belajar Biologi Siswa Kelas $\mathrm{VIII}_{3}$ SMPN 21 Kota Bengkulu. Skripsi UNIB. Tidak Dipublikasikan

Kosasih. 2014. Strategi Belajar dan Pembelajaran. Bandung: Yrama Widya

Kunandar. 2011. Langkah Mudah Penelitian Tindakan Kelas. Jakarta: Rajawali Press

Rusman. $2014 . \quad$ Model-Model Pembelajaran Mengembangkan Profesionalisme Guru. Jakarta: Rajawali Press

Sani, R.A. 2014. Pembelajaran Saintifik untuk Implementasi Kurikulum 2013. Jakarta: PT Bumi Aksara

Trianto. 2011. Penelitian Tindakan Kelas. Jakarta: Tim Prestasi Pustaka

Wisudawati, A.E., Sulistyowati, E. 2014. Metodologi Pembelajran IPA. Jakarta: PT Bumi Aksara. 